\title{
HOW CRUCIAL IS THE WORKING ENVIRONMENT IN SUPPORTING THE PERFORMANCE OF HEALTH WORKERS?
}

\author{
Seberapa Penting Lingkungan Kerja Dalam Mendukung Kinerja \\ Pekerja Kesehatan? \\ *Nuzulul Kusuma Putri \\ Faculty of Public Health, Universitas Airlangga, Surabaya, Indonesia \\ Correspondence*: \\ Address: Kampus C Unair, Surabaya, Indonesia | e-mail: nuzululkusuma@fkm.unair.ac.id
}

In the last semester of the second year of the COVID-19 pandemic, our journal emphasizes its current issue on the life of health workers as humans. We choose to underline the working environment condition as one of the super significant predictors of health workers' performance, leading to a stronger health system in the future.

We always believe that patient safety is the number one priority in healthcare. However, the article written by Nurdin and Wibowo (2021) explains that environmental factors are still barriers to patient safety. Their narrative review found that the low competencies of health workers in understanding patient safety, combined with a working environment that shares shaming and blaming culture, cause the weak reporting of patient safety incidents.

In the other article, our authors also exacerbate the fact that the working environment is not equipped with a solid relationship between health workers, especially with different professional backgrounds. Our author Wahyuni et al. (2021) reported that the working environment in the studied hospital is full of individualism that ruins the collaboration between the health profession. This paper suggests how the utilization of integrated working instruments of the team with different professions and supportive work design will help boost interprofessional communication as the basis of the collaboration itself. Taking pharmacists as the study object, Antari et al. (2021) also reported how the organizational culture significantly affected health workers' performance. A conducive organizational culture works within the health worker's motivation to perform their work as best as possible.

Variations of health conditions make the type of treatment varied between patients. Inspanningsverbintenis, health services performance is not valued based on its result but its process. Hence, procedures standardization is highly needed. Karnadipa (2021) reported that the absence of these standardized procedures among physiotherapists risked their low self-confidence in their professionalism. Another article written by Putra et al. (2021) also highlights that the adequacy of nurses in number and working equipment is related to missed nursing care. Both of these articles show us that a supportive working environment is not only about the ambience of the dayto-day surrounding working space, but working infrastructures that guide and protect the health workers are also still needed.

Regarding to our main editorial on the working environment, our editors have also chosen to publish articles that help the health management select the proper method to support their daily working process.

After a long time, we never received any work on inventory planning of the health industry. A paper written by Yudianti et al. (2021) reflects which inventory planning method is robust. The article claimed that the combination of EOQ and ROP methods in a hospital had increased efficiency in managing disposable medical materials. Dahlui et al. 
(2021) emphasized how important the economic evaluation studies were in helping the health system understand about the effectivity of health intervention.

However, in the second year of the COVID-19 pandemic, we still received many studies related to the urgency of policies regarding the pandemic. Wirawan et al. (2021) highlighted how this pandemic seemed to be a cycle of grief that weakens population performance in exercising preventive behaviour. The more population fell to a more profound economic crisis, the more population tends to neglect the COVID-19 control measures. These findings are supported by the study of Jayawickrama et al. (2021). They presented a narrative review on how derivation of mitigation policies was crucial to ensure that the health system was working effectively during the pandemic. The direction of policymakers in mitigation is a valid indicator to predict the health system's future. Hence, there is urgent work to read how mitigation policy in each country has worked well. When it is weak or unclear enough to ensure that policy supports pandemic mitigation, it must indicate whether it is an unstable health system or the contrary. This paper raises an essential issue in measuring that a health system is on its right track to achieve a more effective and responsive health system.

All in all, these current journal issues show us the importance of the working environment in the health system. As the motor of the health system, health workers need to be supported by a conducive working environment. Preparing the working infrastructure is as crucial as preparing the positive working condition. Thus, putting an excellent basis to make the working process more efficient is fruitful for the organization and the health workers themselves.

\section{Abbreviations}

COVID-19: Corona Virus Disease; EOQ: Economic Order Quantity; ROP: Re-Order Point.

\section{Declarations}

Ethics Approval and Consent Participant Not applicable

\section{Conflict of Interest}

The author declares that there is no personal interests that might have affected the performance.

\section{Availability of Data and Materials \\ Not applicable}

\section{Authors' Contribution}

NKP wrote, reviewed, and edited the manuscript.

\section{Acknowledgment \\ Not applicable}

\section{Reference}

Antari, N.P.U., Agustini, N.P.D. and Suena, N.M.D.S. (2021) 'The Performance Differences Between High And Low Sales Turnover Community Pharmacies', Jurnal Administrasi Kesehatan Indonesia, 9(2), $\quad$ p. 135. doi:10.20473/jaki.v9i2.2021.135-149.

Dahlui, M. et al. (2021) 'Economic Evaluation For Health Advocacy And Informed Policy', Jurnal Administrasi Kesehatan Indonesia, 9(2), p. 202. doi:10.20473/jaki.v9i2.2021.202-209.

Jayawickrama, W.I.U. et al. (2021) 'Policy Perspectives Of Mitigation And Recovery During Covid-19 Pandemic: A Narrative Review', Jurnal Administrasi Kesehatan Indonesia, 9(2), p. 161. doi:10.20473/jaki.v9i2.2021.161-179.

Karnadipa, T. (2021) 'Physiotherapy Service Without Standardized Operating Procedures From Physiotherapist's Perspective: A Case Study', Jurnal Administrasi Kesehatan Indonesia, 9(2), p. 191. doi:10.20473/jaki.v9i2.2021.191-201.

Nurdin, D.A. and Wibowo, A. (2021) 'Barriers To Reporting Patient Safety Incident In Healthcare Workers: Integrative Literature Review', Jurnal Administrasi Kesehatan Indonesia, 9(2), p. 210. doi:10.20473/jaki.v9i2.2021.210-217. 
Putra, K.R. et al. (2021) 'The Correlation Availability Nurses And Equipment With Acute Missed Nursing Care At Hospitals', Jurnal Administrasi Kesehatan Indonesia, 9(2), p. 150. doi:10.20473/jaki.v9i2.2021.150-160.

Wahyuni, S., Lestari, N.D. and Syahrizal, D. (2021) 'Communication Of Professional Caregivers In Establishing Interprofessional Collaboration At Meuraxa Hospital, Banda Aceh', Jurnal Administrasi Kesehatan Indonesia, 9(2), p. 110. doi:10.20473/jaki.v9i2.2021.110-123.
Wirawan, G.B.S. et al. (2021) 'Economic Insecurity And Stress As Determinants Of Covid-19 Preventive Behaviour In Denpasar', Jurnal Administrasi Kesehatan Indonesia, 9(2), p. 124. doi:10.20473/jaki.v9i2.2021.124-134. Yudianti, N.W.Y. et al. (2021) 'Inventory Control Of Disposable Medical Materials At The Bali Mandara Eye Hospital', Jurnal Administrasi Kesehatan Indonesia, 9(2), p. 180. doi:10.20473/jaki.v9i2.2021.180-190. 